\title{
ANTIMICROBIAL SUSCEPTIBILITY OF CAMPYLOBACTER sp STRAINS ISOLATED FROM CALVES WITH AND WITHOUT DIARRHEA IN MINAS GERAIS STATE, BRAZIL
}

\author{
Karina Leite Miranda; Andrey Pereira Lage* \\ Laboratório de Bacteriologia Aplicada, Núcleo de Pesquisa em Saúde Animal, Departamento de Medicina Veterinária \\ Preventiva, Escola de Veterinária, Universidade Federal de Minas Gerais, Belo Horizonte, MG, Brasil
}

Submitted: June 06, 2006; Returned to authors for corrections: November 13, 2006; Approved: March 19, 2007.

\begin{abstract}
The antimicrobial susceptibility of 25 Campylobacter sp strains isolated from calves with and without diarrhea -7 C. coli, 16 C. fetus and 2 C. jejuni - was studied by the disk diffusion method. Eleven antimicrobial agents were tested amikacin, ampicillin, kanamycin, chloramphenicol, erythromycin, gentamicin, neomycin, nitrofurantoin, penicillin G, tetracycline and sulfamethoxazole-trimethoprim. All Campylobacter sp strains were susceptible to amikacin, ampicillin, chloramphenicol, erythromycin, gentamicin, neomycin and nitrofurantoin. Three strains were moderately susceptible to kanamycin $(2 \mathrm{C}$. coli and 1 C. fetus). All the strains were resistant to penicillin G. Two $C$. fetus strains were moderately susceptible to sulfamethoxazoletrimethoprim and $1 C$. coli, 9 C. fetus and 2 C. jejuni strains were resistant. Two C. fetus strains were moderately susceptible to tetracycline and 3 C. coli, 2 C. fetus and $1 C$. jejuni strains were resistant. Eleven strains showed multidrug resistance ( 2 C. coli, 8 C. fetus and $1 C$. jejuni). There was no correlation between resistance of Campylobacter sp strains to antimicrobials and the occurrence of diarrhea in calves. The frequency of resistance and, most importantly, multi drug resistance found among Campylobacter sp strains isolated from calves in Minas Gerais, Brazil, were high and the patterns of resistance observed are related to the antimicrobials agents most largely used in cattle in Brazil.
\end{abstract}

Key words: Campylobacter sp, calf, diarrhea, antimicrobial agents, susceptibility

\section{INTRODUCTION}

Campylobacter jejuni and C. coli are some of the most frequent infectious agents of gastroenteritis in the world (8). In domestic animals they cause diarrhea, but they are also frequently isolated from asymptomatic animals $(22,25)$. C. jejuni and $C$. coli are agents of great importance in patients with travelers' diarrhea and infected with human immunodeficiency virus (HIV) and who, therefore, need antimicrobial therapy (8). Erythromycin, fluoroquinolones and tetracycline are the drugs of choice for treating Campylobacter sp diarrhea (31). C. fetus is divided in two subspecies: $C$. fetus subsp. venerealis, which colonize the bovine reproductive tract and causes abortion and subfertility in cattle, and C. fetus subsp. fetus, whose habitat is the bovine gastrointestinal tract and causes diarrhea $(3,18)$ and sporadically abortion in cattle and sheep $(33)$. In humans, $C$. fetus infections usually cause septicemia and extraintestinal infections that require parenteral therapy (33). In these cases, gentamicin associated with ampicillin is the treatment of choice (13).

Domestic animals play an important role in the epidemiology of human intestinal infection caused by Campylobacter sp. Domestic and wild birds, pigs, cattle, dogs and cats may be considered important reservoirs of Campylobacter sp (8), constituting possible sources of infection for humans. Diarrhea outbreaks in humans caused by $C$. jejuni and C. coli are

*Corresponding Author. Mailing address: Universidade Federal de Minas Gerais - Lab. de Bacteriologia Aplicada - Núcleo de Pesquisa em Saúde Animal - Departamento de Medicina Veterinária Preventiva - Escola de Veterinária - Av. Antônio Carlos, 6627 Caixa Postal 567 CEP $30123-970$ Belo Horizonte, MG, Brasil. Tel.: (31) 3499-2081 Fax: (31) 3499-2080. E-mail: alage@ @et.ufmg.br 
frequently associated with contaminated water and ingestion of unpasteurized milk. The consumption of raw chicken, pig and beef meat is also associated with sporadic cases of human diarrhea (8).

Antimicrobials are used in food animals as therapeutic agents and as growth promoters. The use of effective drugs has been essential to guarantee the high indices of productivity reached in the last decades, propitiating a reduction of mortality and morbidity and the maintenance of animal well-being. However, the indiscriminate use of antimicrobials can lead to the selection of resistant bacteria in food animals that could subsequently be transmitted to humans, a serious public health problem (23). Resistance to antimicrobials exists even before they were actually applied by humans, but this intrinsic form of resistance is not the major cause of concern about animal and human health. The great majority of the resistant microorganisms are the result of genetic changes, due to mutations or transference of genetic material, followed by a selection process, which happens mostly because an indiscriminate use of antimicrobials $(23,29)$.

Antimicrobial susceptibility test represents one of the most important tasks of the clinical microbiology laboratory. It can be used as an epidemiological tool and for the definition of the proper treatment of infections, consequently preventing or creating strategies that minimize the dissemination of resistant bacterial strains, mainly multiresistant ones. With the observed increase in drug resistance, the study of antimicrobial susceptibility of any routinely isolated strain becomes important, mainly of Campylobacter sp strains, since studies on the susceptibility profile of Campylobacter sp strains isolated in Brazil are still rare.

The aim of this study was to determine the antimicrobial susceptibility of Campylobacter sp strains isolated from calves up to 60 days of age, with and without diarrhea, in Minas Gerais State, Brazil.

\section{MATERIALAND METHODS}

A total of 25 Campylobacter sp strains were tested. The strains were isolated from calves up to 60 days of age, with and without diarrhea, from dairy farms in Minas Gerais State, Brazil, from May 1990 to February $1991(18,19)$. The distribution of Campylobacter species and the clinical state of the calves are shown in Table 1.

The disk diffusion method was performed according to Woods and Washington (37). Campylobacter sp were grown in BHI agar (Difco, USA), at $37^{\circ} \mathrm{C}$, under a microaerophilic condition $\left(85 \% \mathrm{~N}_{2}, 10 \% \mathrm{CO}_{2}, 5 \% \mathrm{O}_{2}\right)$, for $48 \mathrm{~h}$. After incubation all strains were suspended in PBS pH 7.4 and density was adjusted to the $0.5 \mathrm{McF}$ arland turbidity standard and inoculated on Mueller-Hinton agar plates (Difco, USA) supplemented with $5 \%$ of horse blood. Inoculated plates were incubated at $37^{\circ} \mathrm{C}$
Table 1. Isolates of Campylobacter sp from calves up to 60 days of age, with and without diarrhea in Minas Gerais State, Brazil ${ }^{1}$.

\begin{tabular}{ccccc}
\hline Clinical State & \multicolumn{3}{c}{ Species } & Total \\
\cline { 2 - 4 } & C. coli & C. fetus & C. jejuni & \\
\hline Diarrhea & 1 & 8 & 1 & 10 \\
Normal & 6 & 8 & 1 & 15 \\
\hline Total & 7 & 16 & 2 & 25 \\
\hline
\end{tabular}

1. All strains were isolated from calves in Minas Gerais State, Brazil, during the period from May 1990 to February 1991.

under a microaerophilic atmosphere, for $48 \mathrm{~h}$. Disks of the following antimicrobial agents were used: amikacin $30 \mu \mathrm{g}$, ampicillin $10 \mu \mathrm{g}$, kanamycin $30 \mu \mathrm{g}$, chloramphenicol $30 \mu \mathrm{g}$, erythromycin $15 \mu \mathrm{g}$, gentamicin $10 \mu \mathrm{g}$, neomycin $30 \mu \mathrm{g}$, nitrofurantoin $300 \mu \mathrm{g}$, penicillin G $10 \mu \mathrm{g}$, trimethoprimsulfamethoxazole 1,25/23,75 $\mu \mathrm{g}$ (sulfazotrim) and tetracycline $30 \mu \mathrm{g}$. All disks were supplied by Cecon (São Paulo - Brazil). After incubation, the inhibition zones were measured and the susceptibility patterns were determined (37).

Fisher and $\chi^{2}$ tests were employed to study the correlation between resistant Campylobacter sp strains and the occurrence of diarrhea in animals (28).

\section{RESULTS}

All Campylobacter sp strains tested were susceptible to amikacin, ampicillin, cloramphenicol, erythromycin, gentamicin, neomycin and nitrofurantoin. Three strains $(12 \%)$ were moderately susceptible to kanamycin (Table 2). Two strains (8\%) were moderately susceptible and six (24\%) strains were resistant to tetracycline. Twenty-two (100\%) of the tested strains were resistant to penicillin G; 9 were from animals with diarrhea. Two strains $(8 \%)$ were moderately susceptible and $12(48 \%)$ were resistant (Table 2) to the combination sulfamethoxazole-trimetoprim.

Twelve strains (48\%) showed multidrug resistance (Table 3), which meant that they were resistant to more than one antimicrobial group. Three $C$. coli strains, from 2 animals without and one with diarrhea; 8 C. fetus, 4 from animals with and 4 from animals without diarrhea, and one $C$. jejuni strain, isolated from an animal without diarrhea, showed multidrug resistance. There was no correlation between the resistance of Campylobacter $\mathrm{sp}$ strains to antimicrobials and the occurrence of diarrhea in calves.

\section{DISCUSSION}

Antimicrobial resistance of microorganisms is a real concern, especially in veterinary medicine, because of the interrelation 
Table 2. Susceptibility to kanamycin, combination of sulfamethoxazole-trimethoprim and tetracycline of Campylobacter sp strains isolated from calves up to 60 days of age in Minas Gerais State, Brazil ${ }^{1}$.

\begin{tabular}{|c|c|c|c|c|c|c|c|c|c|}
\hline \multirow[t]{3}{*}{ Antimicrobials } & & \multicolumn{6}{|c|}{ Species } & \multicolumn{2}{|c|}{ Total } \\
\hline & & \multicolumn{2}{|c|}{ C. coli } & \multicolumn{2}{|c|}{ C. fetus } & \multicolumn{2}{|c|}{ C. jejuni } & \multirow[b]{2}{*}{$\mathrm{D}$} & \multirow[b]{2}{*}{$\mathrm{N}$} \\
\hline & & $\mathrm{D}^{2}$ & $\mathrm{~N}^{3}$ & $\mathrm{D}$ & $\mathrm{N}$ & D & $\mathrm{N}$ & & \\
\hline \multirow[t]{3}{*}{ Kanamycin } & $\mathrm{S}^{4}$ & 0 & 5 & 8 & 7 & 1 & 1 & 9 & 13 \\
\hline & $\mathrm{M}^{5}$ & 1 & 1 & 0 & 1 & 0 & 0 & 1 & 2 \\
\hline & $\mathrm{R}^{6}$ & 0 & 0 & 0 & 0 & 0 & 0 & 0 & 0 \\
\hline \multirow[t]{3}{*}{ Sulfazotrim ${ }^{7}$} & S & 0 & 6 & 2 & 3 & 0 & 0 & 2 & 9 \\
\hline & $\mathrm{M}$ & 0 & 0 & 2 & 0 & 0 & 0 & 2 & 0 \\
\hline & $\mathrm{R}$ & 1 & 0 & 4 & 5 & 1 & 1 & 6 & 6 \\
\hline \multirow[t]{3}{*}{ Tetracycline } & S & 0 & 4 & 6 & 6 & 0 & 1 & 6 & 11 \\
\hline & $\mathrm{M}$ & 0 & 0 & 2 & 0 & 0 & 0 & 2 & 0 \\
\hline & $\mathrm{R}$ & 1 & 2 & 0 & 2 & 1 & 0 & 2 & 4 \\
\hline
\end{tabular}

1 - All strains were isolated from calves in Minas Gerais State, Brazil, during the period from May 1990 to February 1991. 2 - D - diarrhea; 3 $\mathrm{N}$ - normal; 4 - $\mathrm{S}$ - susceptible; 5 - M - moderately susceptible; 6 - $\mathrm{R}$ resistant; 7 -Sulfamethoxazol + trimethoprim; $\mathrm{P}>0,05$ for all comparisons.

Table 3. Patterns of multiple resistance to antimicrobial agents of Campylobacter sp strains isolated from calves up to 60 days of age, in Minas Gerais State, Brazil ${ }^{1}$.

\begin{tabular}{ccccccc}
\hline $\mathrm{N}^{2}$ & $\mathrm{D}^{3}$ & Species & Kanamycin & Penicillin & Sulfazotrim & Tetracycline \\
\hline 1 & 1 & C. coli & $\mathbf{M}^{4}$ & $\mathbf{R}^{5}$ & $\mathbf{R}$ & $\mathbf{R}$ \\
2 & 0 & C. coli & $\mathrm{S}^{6}$ & $\mathbf{R}$ & $\mathrm{S}$ & $\mathbf{R}$ \\
6 & 2 & C. fetus & $\mathrm{S}$ & $\mathbf{R}$ & $\mathbf{R}$ & $\mathrm{S}$ \\
2 & 2 & C. fetus & $\mathrm{S}$ & $\mathbf{R}$ & $\mathbf{R}$ & $\mathbf{R}$ \\
1 & 0 & C. jejuni & $\mathrm{S}$ & $\mathbf{R}$ & $\mathbf{R}$ & $\mathbf{R}$
\end{tabular}

1 - All strains were isolated from calves in Minas Gerais State, Brazil, during the period from May 1990 to February 1991.2 - Number of strains with the same resistance profile; 3 - Number of strains isolated from diarrheic animals; $4-\mathrm{M}$ - moderately susceptible; 5 - R - resistant; 6-S - susceptible.

between resistance found in strains of animal origin and humans. The husbandry adopted on several dairy farms, such as raising calves in calf barns, where procedures of hygiene are more difficult, propitiates the dissemination of pathogens and disease with a consequent increase in antimicrobial use. On many dairy farms, one-day old calves are housed separately to control infection and fed milk or milk replacer, which may contain antibiotics. Moreover, antimicrobials, mainly tetracycline, sulfonamides and penicillin are used in calves to prevent diarrhea and pneumonia (23). Another common practice in veterinary medicine is the use of subdoses of antibiotics as growth promoters in livestock. This preventive use of antibiotics contributes to the high frequency of bacterial resistance in microbiota of poultry, swine and cattle (23). The results of the present study may reflect those problems associated with the veterinary use of antibiotics as the higher resistance patterns were found to antimicrobials largely employed for treating cattle infections or as growth promoters $(5,30)$.

Some authors compared methods for antibiotic susceptibility testing of Campylobacter species and concluded that the disk diffusion method may constitute a simple, inexpensive, accurate and reliable antimicrobial testing method for Campylobacter strains $(10,14)$.

The lack of correlation between the occurrence of diarrhea in calves and resistance to antimicrobials among the Campylobacter sp strains in the present study might be associated to the reduced number of strains tested. However, as animals are usually raised under similar conditions, it just can reflect that most animals are submitted to the same risk factors for the appearance of antimicrobial resistance.

Diarrhea outbreaks caused by $C$. jejuni and $C$. coli are frequently associated to unpasteurized milk and raw chicken, pork and beef meat ingestion (8), what emphasizes even more the importance of studies on susceptibility of Campylobacter sp. strains isolated from animals to the antibiotics of current use in human medicine or to the drugs of choice for treating Campylobacter infections. In the present study, all the isolated strains of Campylobacter sp. were susceptible to erythromycin, the drug of first choice for the treatment of human enteric infection caused by $C$. jejuni and $C$. coli. Some studies have already demonstrated the development of resistance of $C$. jejuni and $C$. coli strains to erythromycin $(2,11,15,40,35)$, although Gaudreau and Gilbert (14), in Canada, did not find resistant $C$. jejuni strains to this antimicrobial. In general, strains isolated from swine present higher rates of resistance to erythromycin, because macrolides are largely used to control respiratory diseases in this species $(30,32)$. Aarestrup et al. (1) reported that the wide use of tylosin in Denmark was probably responsible for the high rates of resistance of $C$. coli and $C$. jejuni strains to macrolides in swine. Although many products containing macrolides have been approved for treating cattle with respiratory, hoof and mastitis problems in Brazil (30), their use does not seem to influence the appearance of resistance in Campylobacter sp strains, probably because of their restricted use in cattle production due to their high costs.

In the present study, all the tested strains were susceptible to the drugs of choice for the treatment of systemic infection caused by $C$. fetus, gentamicin and ampicillin. Tremblay et al. 
(34) also reported all C. fetus strains isolated in Canada as susceptible to both antibiotics. Alfredson et al. (2) demonstrated the occurrence of resistance to ampicillin among Australian isolates and Sáenz et al. (27), in a study performed in Spain, reported the occurrence of resistant Campylobacter sp. strains to ampicillin and gentamicin. Sáenz et al. (27) also found rates of resistance to amikacin varying from 0 to $21.6 \%$, contrasting with the findings of the present study, where all the strains were susceptible to this antibiotic. In a study performed in Spain (27), high rates of resistance to kanamycin in $C$. jejuni and $C$. coli strains isolated from food animals and food of animal origin were found. In the present study, no resistant strain to kanamycin was found, but $12 \%$ of the tested strains were moderately susceptible to this antibiotic. In spite of all the Campylobacter sp strains studied being susceptible to aminoglycosides, care should be taken with this group of antimicrobial agents due to its large use in cattle in Brazil $(5,30)$.

Similar results as those found in the present study, showing a lack of resistance to chloramphenicol among Campylobacter sp isolates, were reported by Sáenz et al. (27) in Spain. Larivière et al. (20) demonstrated a very low resistant rate of Campylobacter sp strains to chloramphenicol, varying from 0.6 to $10 \%$. However, despite the good activity of chloramphenicol against Campylobacter sp, its use in food animals was forbidden in Brazil because of the risks that residues of this drug in meat, milk and eggs may cause to public health (6).

Vanhoof et al. (35) and Butzler and Skirrow (7) observed that aminoglycosides, chloramphenicol and tetracyclines have a good activity on isolates of $C$. jejuni from domestic animals. However, the occurrence of strains resistant to tetracycline has been reported by several authors $(2,14,27,34,35)$. Aarestrup et al. (1), in a study performed in Denmark, observed that the resistance to tetracycline is more common in strains isolated from humans than from domestic animals. In Brazil, some studies $(9,17,24)$ show the occurrence of strains resistant to tetracycline. However, Aquino et al. (4) did not find any Campylobacter sp strain isolated from men resistant to this antibiotic, but they reported resistance in strains isolated from swine. In the present study, $8 \%$ of the tested strains were moderately susceptible and $24 \%$ were resistant to this antibiotic, what is a remarkable finding, because tetracycline is one of the drugs of choice for treatment of $C$. jejuni and C. coli enteric infections. This may reflect the large use of tetracycline in cattle production in Brazil (30).

Vargas et al. (36) determined the susceptibility of 21 Brazilian isolates of $C$. fetus subsp. venerealis to the antimicrobial agents that are usually used for therapeutic and semen treatment. Resistance was only found to lincomycin (42.86\%), enrofloxacin $(4.76 \%)$ and nalidixic acid (100\%), evidencing susceptibility of C. fetus subsp. venerealis strains to antimicrobials usually used for clinical and semen treatment. In the present study, from the 16 C. fetus strains tested, $12.5 \%$ were resistant to tetracycline,
$56.25 \%$ were resistant to sulfazotrim and all of them were resistant to penicillin, what it is a highly concerning finding, since some authors point out penicillin and streptomycin as the most used drugs to control $C$. fetus infections $(12,16)$.

In the last years, multiresistant Campylobacter sp strains have been reported $(4,21,26)$ and their frequencies are of concern for human and animal health authorities. In Brazil, Aquino et al (4) reported C. coli and C. jejuni isolates from human and animal sources that were resistant to sulphonamide, norfloxacin, erythromycin, ciprofloxacin, ampicillin and tetracycline. Although the multiresistance patterns were different, the high frequency of multiresistant Campylobacter sp strains (48\%), found in the present study, suggests that strict norms to the use of antimicrobials in veterinary medicine should be adopted in Brazil. The cases of multiresistance found were probably related to an indiscriminate and incorrect use of antimicrobials frequently observed in the production of cattle. Animals and food from animal origin play an important role in the transmission of campilobacteriosis to humans. So the findings of multi resistant Campylobacter sp strains from domestic animals stressed the importance of epidemiological surveillance and preventive actions that may avoid the dissemination of these strains over animal and human populations (23).

The resistance patterns of Campylobacter sp strains found in this study are correlated to the antimicrobials agents most widely used in veterinary medicine in Brazil. Therefore monitoring resistance of Campylobacter sp strains from different geographic regions to antimicrobials must be a priority. Epidemiological studies of the risk factors associated to the development of resistance to antimicrobials are of great importance to increase the useful life of antimicrobial agents important in veterinary medicine, as well as for the treatment of human infections.

\section{ACKNOWLEDGEMENTS}

K. L. Miranda and A. P. Lage were indebted to Conselho Nacional de Desenvolvimento Científico e Tecnológico - CNPq for the fellowships. This study was supported by CNPq, Fapemig and FEP - MVZ Coordenação Preventiva.

\section{RESUMO}

\section{Susceptibilidade a antimicrobianos de amostras de Campylobacter sp isoladas de bezerros com e sem diarréia, no estado de Minas Gerais, Brasil}

Foi estudado o perfil de susceptibilidade aos antimicrobianos de 25 amostras de Campylobacter sp isoladas de bezerros com e sem diarréia ( 7 C. coli, 16 C. fetus e 2 C. jejuni). Foram testados pelo método de difusão 11 agentes antimicrobianos: amicacina, ampicilina, canamicina, cloranfenicol, eritromicina, gentamicina, 
neomicina, nitrofurantoína, penicilina G, tetraciclina e sulfametoxazole-trimetoprim. Todas as amostras de Campylobacter sp foram susceptíveis a amicacina, ampicilina, cloranfenicol, eritromicina, gentamicina, neomicina e nitrofurantoína. Três amostras foram moderadamente sensíveis à canamicina $(2 C$. coli e $1 C$. fetus $)$. Todas as amostras foram resistentes à penicilina G. Duas amostras de C. fetus foram moderadamente sensíveis a sulfametoxazole-trimetoprim e $1 C$. coli, 9 C. fetus e 2 C. jejuni foram resistentes. Duas amostras de C. fetus foram moderadamente sensíveis à tetraciclina e 3 de $C$. coli, 2 de $C$. fetus e 1 de $C$. jejuni foram resistentes. Onze amostras apresentaram multirresistência ( 2 C. coli, 8 C.fetus e 1 C. jejuni). Não houve correlação entre resistência de amostras de Campylobacter sp aos antimicrobianos e a ocorrência de diarréia nos bezerros. A frequência de resistência e, principalmente, a multirresistência encontradas nas amostras Campylobacter sp isoladas de bezerros em Minas Gerais, Brasil, foram altas. O perfil de resistência de amostras de Campylobacter $\mathrm{sp}$ observado está relacionado aos agentes antimicrobianos mais utilizados em bovinos no Brasil.

Palavras chave: Campylobacter sp, bezerro, diarréia, antimicrobianos, sensibilidade

\section{REFERENCES}

1. Aarestrup, F.M.; Nielsen, E.M.; Madsen, M.; Engberg, J. (1997). Antimicrobial susceptibility of thermophilic Campylobacter ssp. From humans, pigs, cattle and broilers in Denmark. Ant. Agent. Chemoter., 41, 2244-50.

2. Alfredson, D.A.; Akhurst, R.J.; Korolik, V. (2003). Antimicrobial resistance and genomic screening of clinical isolates of thermophilic Campylobacter spp. from south-east Queensland, Australia. J. of appl. Microbiol., 94, 495-500.

3. Al-Mashat, R.R.; Taylor, D.J. (1980) Campylobacter spp in enteric lesions in cattle. Vet. Record, 107, 31-34.

4. Aquino, M.H.C., Filgueiras, A.L.L.; Ferreira, M.C.S.; Oliveira, S.S.; Bastos, M.C.; Tibana, A. (2002). Antimicrobial resistance and plasmid profiles of Campylobacter jejuni and Campylobacter coli from human and animal sources. Lett. Appl. Microbiol., 34, 149-153.

5. Booth, N.; McDonald, L.E. (1992). Farmacologia e terapêutica em veterinária. Guanabara Koogan, Rio de Janeiro.

6. Brasil. Ministério da Agricultura e do Abastecimento. (1998). Portaria no. 448, de 10 de setembro de 1998. Diário Oficial da União. 11 de setembro de 1998. p.38.

7. Butzler, J.P.; Skirrow, M.B. (1979). Campylobacter enteritis. Clin. Gastroenterol., 8, 737-65.

8. Butzler, J.P. (2004). Campylobacter, from infection to celebrity. Clin. Microbiol. Infect., 10, 868-876.

9. Dias, T.C.; Queiroz, D.M.M.; Mendes, E.N.; Peres, J.N. (1990). Chicken carcasses as a source of Campylobacter jejuni in Belo Horizonte, Brasil. Rev. Inst. Med. Trop. São Paulo., 32, 414-8.

10. Engberg, J.; Andersen, S.; Skov, R.; Aarestrup, F.M.; Gerner-Smidt, P. (1999). Comparison of two agar dilution methods, including Etest, for antibiotic susceptibility testing of thermophilic Campylobaster species. Clin. Microbiol. Infect., 5, 580-584.

11. Engberg, J.; Aarestrup, F.M.; Taylor, D.E.; Gerner-Smisdt, P.; Nachamkin, I. (2001). Quinolone and macrolide resistance in
Campylobacter jejuni and C. coli: resistance mechanisms and trends in human isolates. Emerg. Infect. Dis., 7, 24-34.

12. Garcia, M.M.; Eaglesome, M.D.; Rigby, C. (1983). Campylobacters important in veterinary medicine. Vet. Bull., 53, 793-817.

13. Gaunt, P.N.; Piddock, V.J. (1996). Ciprofloxacin resistant Campylobacter spp. in humans an epidemiological and laboratory study. J. Antimicrob. Chemother., 37, 747-757.

14. Gaudreau, C.; Gilbert, H. Antimicrobial resistance of clinical strains of Campylobacter jejuni subsp. jejuni isolated from 1985 to 1997 in Quebec, Canada. Antimicrob. Agents Chemother., 42, 2106-2108, 1998.

15. Hoge, C.W.; Gambel, J.M.; Srijan, C.; Pitarangsi, C.; Echeverria, P. (1998). Trends in antibiotic resistance among diarrheal pathogens isolated in Thailand over 15 years. Clin. Infect. Dis., 26, 341-345.

16. Hum, S.; Brunner, J.; Gardiner, B. (1993). Failure of therapeutic vaccination of a bull infected with Campylobacter fetus. Aust. Vet. $J ., 70,386-387$.

17. Jaramillo, H.F. (1983). Espécies termófilas de Campylobacter: aspectos bacteriológicos, epidemiológicos e patogênicos. São Paulo, Brasil, 144p. (Ph.D. Thesis. Escola Paulista de Medicina)

18. Lage, A.P. (1992). Estudo das espécies termotolerantes de Campylobacter isoladas de bezerros com e sem diarréia. Belo Horizonte, Brasil, 48p. (Msc. Dissertation.. Escola de Veterinária. UFMG).

19. Lage, A.P.; Carvalho, A.C.T.; Leite, R.C. (1992). Comparison of procedures for isolating Campylobacter sp from diarrheic and normal calves. Rev. Microbiol., 23, 151-4.

20. Larivière, L.A.; Gaudreau, C.L.; Turgeon, F.F. (1986). Susceptibility of clinical isolates of Campylobacter jejuni to twenty-five antimicrobial agents. J. Antimicrob. Chemother, 18, 681-685.

21. Lee, B.C.; Reimers, N.; Barnes, H.J.; D'lima, C.; Carver, D.; Kathariou, S. (2005). Strain persistence and fluctuation of multiple-antibiotic resistant Campylobacter coli colonizing turkeys over successive production cycles. Foodborne Pathog. Dis., 2, 103-110.

22. Marks, S.L.; Kather, E.J. (2003). Bacterial-associated diarrhea in the dog: a critical appraisal. Vet. Clin. North Am. Small Anim. Pract., 33, 1029-60.

23. McEwen, S.E.; Fedorka-Cray, P.J. (2002). Antimicrobial use and resistance in animals. Clin. Infect. Dis., 34, 93-106.

24. Mendes, E.N. (1985). Freqüência de Campylobacter jejuni em crianças com e sem diarréia em Belo Horizonte. Belo Horizonte, Brasil. 109p. (Msc. Dissertation. Instituto de Ciências Biológicas. UFMG).

25. Modolo, J.R.; Bisping, W.; Kirpal, G. (1987). Isolamento de Campylobacter sp de bezerros com e sem diarréia. Pesq. Vet. Bras. 7, 23-25.

26. Payot, S.; Dridi, S.; Laroche, M.; Federighi, M.; Magras, C. (2004) Prevalence and antimicrobial resistance of Campylobacter coli isolated from fattening pigs in France. Vet. Microbiol., 101, 91-99.

27. Sáenz, Y.; Zarazaga, M.; Lantero, M.; Gastañares, M.J.; Baquero, F.; Torres, C. (2000). Antibiotic resistance in Campylobacter strains isolated from animals, foods and humans in Spain in 1997-1998. Antimicrob. Agents Chemother., 44, 267-271.

28. Sampaio, I.B.M. (1998). Estatística aplicada à experimentação animal. Fundação de Ensino e Pesquisa em Medicina Veterinária e Zootecnia, Belo Horizonte, Brasil, 221p.

29. Shea, K.M. (2003). Antibiotic resistance: what is the impact of agricultural uses of antibiotics on children's health? Pediatrics., 112, 253-258

30. Sindan. Compêndio de Produtos Veterinários. (2006). Available at http://www.cpvs.com.br/cpvs/index.html. Accessed 20 may 2005

31. Skirrow, M.B.; Blaser, M.J. (2000). Clinical aspects of Campylobacter infection. In: Nachamkim, I.; Blaser, M.J. (eds). Campylobacter. American Society for Microbiology, Washington D.C., USA, p.6988. 
32. Straw, B.E.; D'Allaire, S.; Mengeling, W.L.; Taylor, D.J. (1999). Diseases of swine. Blackwell Science, Oxford, 1209p.

33. Thompson, S.A.; Blaser, M.J. (2000). Pathogenesis of Campylobacter fetus infections. In: Nachamkin, I.; Blaser, M.J. (eds). Campylobacter. American Society for Microbiology, Washington D.C., USA, p.321-347.

34. Tremblay, C.; Gaudreau, C.; Lorange, M. (2003). Epidemiology and antimicrobial susceptibilities of 111 Campylobacter fetus subsp. fetus strains isolated in Quebec, Canada, from 1983 to 2000. J. clin. Microbiol., 41, 463-466.

35. Vanhoof, R.; Gordts, B.; Dierickx, R.; Coignau, H.; Butzler, J. P. (1980). Bacteriostatic and bactericidal activities of the 24 antimicrobial agents against Campylobacter fetus subsp. jejuni. Ant. Agents Chemoter., 18, 118-21.

36. Vargas, A.C.; Costa, M.M.; Groff, A.C.M.; Viana, L.R.; Krewer, C.C.; Spricigo, D.A.; Kirinus, J.K. (2005). Sensibilidade antimicrobiana de Campylobacter fetus subsp. venerealis isolado de bovinos. Pesq. Vet. Bras., 25, 1-3.

37. Woods, G.L.; Washington, J.A. (1995). Antibacterial susceptibility tests: dilution and disk diffusion methods. In: Murray, P.R.; Baron, E.J.; Pfaller, M.A.; Tenover, F.C., Yolken, R.H. (eds). Manual of Clinical Microbiology. ASM Press, Washington, USA, p.13271341 . 